\title{
The role of dendritic cells in graft-versus-tumor effect
}

\section{Tomomi Toubai, Nathan Mathewson and Pavan Reddy*}

Blood and Marrow Transplantation Program, Division of Hematology and Oncology, Department of Internal Medicine, University of Michigan Comprehensive Cancer Center, Ann Arbor, MI, USA

\section{Edited by:}

Kristian Michael Hargadon,

Hampden-Sydney College, USA

\section{Reviewed by:}

Kamil R. Kranc, University of

Edinburgh, UK

Motoko Koyama, QIMR Berghofer

Medical Research Institute, Australia

*Correspondence:

Pavan Reddy, Blood and Marrow Transplantation Program, Division of

Hematology and Oncology,

Department of Internal Medicine

University of Michigan

Comprehensive Cancer Center, 3312

CCGC, 1500 East Medical Center

Drive, Ann Arbor, MI 48105-1942, USA

e-mail: reddypr@med.umich.edu
Dendritic cells (DCs) are the most potent antigen presenting cells. DCs play a pivotal role in determining the character and magnitude of immune responses to tumors. Host and donor hematopoietic-derived DCs play a critical role in the development of graft-versus-host disease (GVHD) following allogeneic hematopoietic cell transplantation. GVHD is tightly linked with the graft-versus-tumor (GVT) effect. Although both host and donor DCs are important regulators of GVHD, the role of DCs in GVT is poorly understood. GVT is caused by donor $T$ cells that attack recipient tumor cells. The donor T cells recognize alloantigens, and tumor specific antigens (TSAs) are mediating GVHD. The process of presentation of these antigens, especiallyTSAs remains unknown. Recent data suggested that DC may be essential role for inducing GVT. The mechanisms that DCs possess may include direct presentation, cross-presentation, cross-dressing. The role they play in GVT will be reviewed.

\section{Keywords: allogeneic hematopoietic stem cell transplantation, graft-versus-tumor effect, dendritic cells}

\section{INTRODUCTION}

Allogeneic hematopoietic cell transplantation (allo-HCT) has become widely used as a curative therapy for a variety of life-threatening hematologic, immunologic, and genetic diseases. However, serious complications endure, presenting as obstacles to successful treatment. One complication is graft-versus-host disease (GVHD) and another is primary disease relapse. The current understanding of the science suggests that the dysregulation and/or dysfunction of the immune system and corresponding immunocompetent cells of recipients after allo-HCT are responsible for these obstacles (1). Current prophylaxis and treatment regimens using immunosuppressants mainly target $\mathrm{T}$ cells for the mitigation of GVHD. Excessive immunosuppression for the treatment of GVHD often results in serious infections (Cytomegalovirus, Herpes zoster virus, fungus, and bacterias), decreases graft-versustumor (GVT) responses (which are the most beneficial effects of allo-HCT), and finally is known to cause relapse of primary disease $(1,2)$. Thus, it is imperative that we develop new strategies of GVHD prophylaxis and treatment while maintaining sufficient GVT effect.

Dendritic cells (DCs), the most potent of the antigen presenting cells (APCs) of both the innate and adaptive immune responses, are critical for the pathophysiology of both GVHD and GVL (1-3). Host and donor hematopoietic-derived APCs (particularly DCs) are critical in the development of GVHD (4-6). In addition, host hematopoietic-derived DCs also play a significant role in GVL (7, 8). In this review, we focus on the role of DCs in GVT and consider strategies for effective utilization in enhancing GVT.

\section{SUBSETS AND FUNCTION OF DENDRITIC CELLS}

Dendritic cells have bilateral characteristics, as DCs are critical for priming $\mathrm{T}$ cell responses in an inflammatory milieu, but are also required for the induction of tolerance at steady state.
Dendritic cells are phenotypically classified under many subtypes. This heterogeneity suggests that better understanding of these distinct subsets may lead to the ability to modify and manipulate DC functions. Lymphoid and non-lymphoid tissues, as well as the blood, contain a variety of DC subsets with a wide range of functions. DCs arise from bone marrow (BM)derived macrophage/DC precursors (MDPs) (9). MDPs differentiate into monocytes, yielding macrophages; common DC precursors (CDPs), which generate classic DC (cDC)-restricted precursors (pre-cDCs); or plasmacytoid DCs (pDCs) (9). However, human equivalents of mouse MDPs and CDPs remain elusive (10). Pre-cDCs migrate from the BM and enter blood circulation destined for lymphoid organs and/or peripheral tissues. Upon arrival, pre-DCs differentiate into lymphoid/non-lymphoid tissue DCs (9). DCs express both the hematopoietic marker CD45 and integrin CD11c. Further, DCs can be divided into two major categories in lymphoid tissues, based upon the intensity of CD11c expression. The first is conventional DCs ( $\mathrm{cDCs}-\mathrm{CD} 11 \mathrm{c}^{\mathrm{high}}$ ) and second is pDCs (pDCs-CD11 $c^{\text {low/int }}$ ). $\mathrm{cDCs}$ are further categorized into lymphoid organ resident DCs and migratory tissue DCs. Both categories of cDCs are also divided into CD8 $\alpha^{+}$DCs (lymphoidderived DCs) and $\mathrm{CD} 8^{+} \alpha^{-} \mathrm{DCs}$ (myeloid-derived DCs) and they show low co-stimulatory molecules in steady state (11-13). In non-lymphoid tissue, there are three types of DCs [tissue-resident steady state DCs, pDCs, and monocyte-derived DCs (moDCs)] in mouse; humans express at least two types of DCs, pDCs, and myeloid-derived DCs that are divided into three different categories: $\mathrm{CD}_{16}{ }^{+} \mathrm{DCs}, \mathrm{BDCA1}^{+}$, and $\mathrm{BDCA}^{+}$DCs. Although DCs expressing certain phenotypes are known to contribute to development of GVHD, but not obligatory (14-16), the function of the remaining phenotypes is less understood. The various subsets are discussed very briefly below and summarized in Table 1, in light of several recent excellent reviews on these subsets $(13,17-19)$. 
Table 1 | Dendritic cell subsets.

\begin{tabular}{|c|c|c|c|}
\hline DC subsets & Surface markers & Transcription factors & Function \\
\hline $\begin{array}{l}\text { Mouse: } \\
\text { CD8 } \alpha^{+} \text {DCs }\end{array}$ & ouse: $\mathrm{CD} 8 \alpha^{+}(11)$ & $\begin{array}{l}\text { FMS-related tyrosine kinase } 3 \\
\text { (Flt3) }(171,172) \\
\text { Interferon regulatory factor } 8 \\
\text { (IRF8) }(24,30)\end{array}$ & $\begin{array}{l}\text { Engulf and process exogenous antigens and } \\
\text { subsequently present these antigens to CD4+ T cells } \\
\text { via MHC class II (13) } \\
\text { Strong cross-presentation capacity (37) }\end{array}$ \\
\hline $\begin{array}{l}\text { Human: } \\
\text { BDCA3+DCs }\end{array}$ & Human: BDCA3+ (CD141)+ (48) & $\begin{array}{l}\text { Inhibitor of DNA binding protein } \\
2(\operatorname{ld} 2)(31,36)\end{array}$ & $\begin{array}{l}\text { Enhancement of CTL responses }(38,39) \\
\text { Secrete large amounts of IL-12 }(38,39)\end{array}$ \\
\hline & $\begin{array}{l}\text { Mouse/human: MHC class } \mathrm{II}^{+}, \mathrm{CD}^{+} 4^{+} \\
(12), \mathrm{CD}^{+}(24), \mathrm{DEC} 205(\mathrm{CD} 205)^{+}(12) \\
\mathrm{Clec}^{+} \mathrm{A}(\mathrm{DNGR}-1)^{+}(22), \mathrm{TLR}^{+}(23) \\
\mathrm{XCR}^{+}(25,46,47)\end{array}$ & $\begin{array}{l}\text { Basic leucine zipper transcription } \\
\text { factor ATF-like } 3 \text { (Batf3) (32) } \\
\text { Nuclear factor interleukin-3 } \\
\text { regulated (Nfil3) (33) } \\
\text { PU.1 (34) } \\
\text { Zinc finger transcription factor } \\
\text { (Zbtb46) (35) }\end{array}$ & $\begin{array}{l}\text { Secretion of type I IFN with TLR3, TLR9, and } \\
\text { plasmodium stimulation }(173,174) \\
\text { Immune modulatory function (13) } \\
\text { Decrease allogeneic T cell proliferation }(28,40,175) \\
\text { Induce FoxP3+ Treg and IL-10 secreting T cells }(40,41) \\
\text { Induction of peripheral self-tolerance (176) }\end{array}$ \\
\hline $\mathrm{CD} 8 \alpha^{-} \mathrm{DCs}$ & $\begin{array}{l}\text { Mouse: CD8 } \alpha^{-}(17), C D 11 b^{+}(17), C D 209 \\
(D C-S I G N)^{+}(51), C D 172 a(\operatorname{Sirp} \alpha)^{+}(52) \\
\text { DC inhibitory receptor } 2(D C I R 2)^{+}(53) \\
\text { dectin-1 (Clec-7a) })^{+}(54)\end{array}$ & $\begin{array}{l}\text { FMS-related tyrosine kinase } 3 \\
\text { (Flt3) (17), lymphotoxin } \beta \\
\text { receptor (LT } \beta \text { R) (17), notch RPB-J } \\
\text { (55), notch receptor } 2 \text { (57), } \\
\text { reticuloendotheliosis homolog B } \\
\text { (RelB) (177), TNF-associated } \\
\text { factor } 6 \text { (TRAF6) (178) }\end{array}$ & $\begin{array}{l}\text { Enhancement of Th2 responses in primary stimulation } \\
\text { (58) } \\
\text { IL-12 production under certain conditions (59) } \\
\text { CD4+ T cell activation (53) } \\
\text { Cross-presentation of particular antigens under } \\
\text { certain conditions }(54,179,180)\end{array}$ \\
\hline $\begin{array}{l}\text { Plasmacytoid } \\
\text { DCs (pDCs) }\end{array}$ & 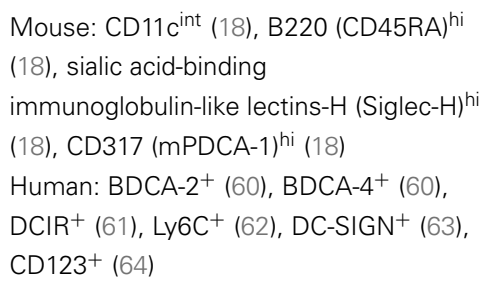 & $\begin{array}{l}\text { Ikaros (68), STAT-3 }(68,181) \text {, } \\
\text { STAT-5 (181) (182) }\end{array}$ & $\begin{array}{l}\text { Secretion of type I IFNs }(18,62) \\
\text { Immunomodulation (18) } \\
\text { Increased cross-presentation capacity (183) }\end{array}$ \\
\hline $\begin{array}{l}\text { Monocyte- } \\
\text { derived } \\
\text { DCs } \\
\text { Inflammatory } \\
\text { DCs (infDCs) }\end{array}$ & 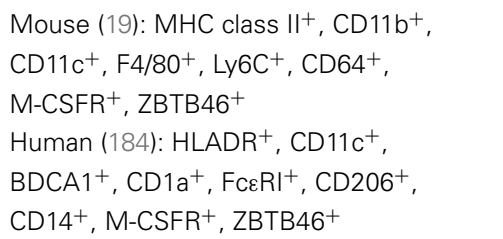 & Unknown & $\begin{array}{l}\text { Migration into the site of inflammation from BM in a } \\
\text { CCR2-dependent manner (77) } \\
\text { Activation and proliferation of T cells (185-188) } \\
\text { Production of various cytokines (185-188) }\end{array}$ \\
\hline $\begin{array}{l}\text { Human: } \\
\text { BDCA1DC } \\
\text { (CD1c }+ \text { DCs) }\end{array}$ & $\begin{array}{l}\mathrm{BDCA}^{+}(60), \mathrm{CD} 11 \mathrm{C}^{+} \text {(79), } \mathrm{HLADR}^{+} \text {(79), } \\
\mathrm{CD}^{+}{ }^{+}(83), \mathrm{CCR}^{+}(83), \mathrm{Fc}^{+} \mathrm{R}^{+}(161)\end{array}$ & Unknown & $\begin{array}{l}\text { Secretion of high levels of IL-12, following TLR4 and } \\
\text { TLR7 stimulation }(83,161) \\
\text { Stimulation of allogeneic T cells (79) } \\
\text { Increased cross-presentation capacity }(46-48,83-85)\end{array}$ \\
\hline
\end{tabular}

\section{CD $8 \alpha^{+}$DCs (MOUSE) AND BDCA3 ${ }^{+}$DCs (HUMAN)}

CD $8 \alpha^{+}$DCs are approximately $20-40 \%$ of total mouse splenic DCs and around $70 \%$ of murine thymic DCs $(11,12)$. In steady state, they express low levels of co-stimulatory molecules, such as CD80, CD86, and CD40 but high levels of MHC class II (20, 21) and highly express CD24, CD36, DEC205 (CD205), Clec9A (DNGR-1), TLR3, and XCR, but show little or no expression of CD172a (Sirp $\alpha)$, CD11b, and DCIR2 (33D1) (12, 2226). The administration of Flt-3L to WT mice dramatically expands $\mathrm{CD} 8 \alpha^{+}$DCs that are phenotypically and functionally matured (27) and have a reduced capacity for allogeneic T cell stimulation (28).
Certain transcription factors play an important role in the development of CD8 $\alpha^{+}$DCs (29-36). Interferon regulatory factor 8 (IRF8) $(29,30)$, inhibitor of DNA binding protein 2 (Id2) (31, 36), the basic leucine zipper transcription factor ATF-like 3 (Batf3) (32), nuclear factor interleukin-3 regulated (Nfil3) (33), PU.1 (34), and zinc finger transcription factor zbtb46 (35) are critical for the development of $C D 8 \alpha^{+}$DCs. Mice lacking these transcription factors exhibit dramatically reduced numbers of $\mathrm{CD} 8 \alpha^{+} \mathrm{DCs}$ while absence of zbtb46, which results in increased CD $8 \alpha^{+}$DCs.

$\mathrm{CD} 8 \alpha^{+} \mathrm{DCs}$ are unique in which they can present exogenous antigens on their MHC class I molecules, a process known as cross-presentation (37). In addition, $\mathrm{CD} 8 \alpha^{+} \mathrm{DCs}$ are critical for 
cytotoxic $\mathrm{T}$ cell (CTL) responses as they are the predominant producers of IL-12 $(38,39)$. On the other hand host-derived CD $8 \alpha^{+}$DCs, expanded by the administration of Flt-3L, decrease allogeneic $\mathrm{T}$ cell responses in vivo (28). We have also found that immunization of donors with host-derived CD $8 \alpha^{+} \mathrm{DCs}$, reduced acute GVHD by increased secretion of IL-10 from donor-derived T cells (40). CD $8 \alpha^{+}$DCs can also induce Foxp $3^{+}$regulatory T cells (Tregs) in a TGF- $\beta$-dependent manner in vitro and in vivo (41). Moreover, $\mathrm{CD} 8 \alpha^{+} \mathrm{DCs}$ are responsible for induction of peripheral self-tolerance by their ability to capture and cross-present tissue-associated antigens to naïve CTLs (42-44) or by CD8 $\alpha^{+}$DCs derived TNF-mediated killing (45).

Although $\mathrm{CD} 8 \alpha^{+}$DCs present only in mice, recent studies have identified human equivalents. BDCA $3^{+}\left(\mathrm{CD} 141^{+}\right)$DCs, which express Clec9A and XCR-1 were identified as human homologs of mouse CD8 $\alpha^{+}$DCs (46-49). BDCA3 ${ }^{+}$DCs have the ability to cross-present soluble or cell-associate antigen to $\mathrm{CD} 8^{+} \mathrm{T}$ cells $(47$, 48). Aside from the capacity for cross-presentation, $\mathrm{BDCA}^{+} \mathrm{DCs}$ produce IFN- $\alpha$ after TLR3 stimulation, similar to $\mathrm{CD} 8 \alpha^{+} \mathrm{DCs}$ homologs in mouse (50).

\section{CD8 $\alpha^{-}$DCs (CD11 b ${ }^{+}$DCs)}

$\mathrm{CD} 8 \alpha^{-}$DCs $\left(\mathrm{CD} 11 \mathrm{~b}^{+} \mathrm{DCs}\right)$ lack expression of the marker CD $8 \alpha$ but express CD11b, which represent a large percentage of splenic or lymphoid resident DCs (17). CD8 $\alpha^{-}$DCs predominately express CD209 (DC-SIGN) (51), CD172a (Sirp $\alpha)$ (52), DC inhibitory receptor 2 (DCIR2) (53), and dectin-1 (Clec-7a) (54). Notch RBP$\mathrm{J}$, is important for development and homeostasis of CD8 $\alpha^{-} \mathrm{DCs}$ (55). Recent reports also suggest that Notch 2 signaling is required for the development of a subset of splenic $\mathrm{CD}_{11 \mathrm{~b}}{ }^{+} \mathrm{DCs}$ $\left(\mathrm{CD}_{11} \mathrm{~b}^{+} \mathrm{ESAM}^{+} \mathrm{DCs}\right)$ and intestinal $\mathrm{CD} 103^{+} \mathrm{CD} 11 \mathrm{~b}^{+} \mathrm{DCs}(56)$, as well as terminal differentiation of CD $8 \alpha^{+}$DCs and CD $11 b^{+}$DCs (57). CD $8 \alpha^{-}$DCs are required to enhance Th2 responses in primary stimulation (58) and also they produce IL-12 under certain conditions (59). CD8 $\alpha^{-}$DCs exist in the marginal zone of the splenic lymphoid follicles and take up, process, and present exogenous antigen to $\mathrm{CD}^{+} \mathrm{T}$ cells via $\mathrm{MHC}$ class II $(17,53)$.

\section{PLASMACYTOID DCs}

Plasmacytoid DCs are distinguished in mice by the expression of CD11cint, B220 (CD45RA $)^{\text {hi }}$, sialic acid-binding immunoglobulin-like lectins- $\mathrm{H}\left(\right.$ Siglec-H) ${ }^{\mathrm{hi}}$, and CD317 (mPDCA$1)^{\text {hi }}$ (18). In human, pDCs express BDCA-2 (60), BDCA-4 (60), DCIR (61), Ly6C (62), DC-SIGN (63), or CD123 (64). Flt3-L is a critical cytokine for the expansion of pDCs $(65,66)$, whereas $\mathrm{HIF}-1 \alpha$ is a negative regulator of $\mathrm{pDC}$ development in vitro and in vivo (67). Ikaros and STAT-3 play a role in the development of pDCs (68). The main function of pDCs is to produce type I interferons (IFN), such as IFN- $\alpha$ and IFN- $\beta$, in response to viral, fungal, and bacterial antigens (18). The role of pDCs in mediating acute GVHD is distinct depending on whether they are derived from the host or donor $(69,70)$.

\section{MONOCYTE-DERIVED DCs}

According to recent reports, monocytes exist in the blood as terminally differentiated cells derived from MDP [whose progenitor is common myeloid precursors (CMPs) in the BM]. In an inflammatory environment, monocytes differentiate into MoDCs, or inflammatory DCs (infDCs) and subsequently migrate into the site of inflammation $(71,72)$. Monocytes also contribute to the development of $\mathrm{CD}_{103}{ }^{-} \mathrm{CD} 11 \mathrm{~b}^{+} \mathrm{DCs}$ in a Csf-1-dependent manner $(73,74)$. Mouse BM-derived DCs generated in vitro with GM-CSF alone or in combination with IL-4 are recognized as equivalent to infDCs because of similar morphology, phenotype, and characteristics $(75,76)$. CCR2 controls the exit of monocytes from the $\mathrm{BM}$ and the migration to the site of inflammation and critical for infDCs. Further, MyD88 and TLRs are known to be required for the maturation and migration of $\operatorname{infDCs}(77,78)$.

\section{HUMAN BDCA1 (CD1c)+ DCs}

Dendritic cells isolated from human are identified as $\mathrm{Lin}^{-}$(CD3, CD19, CD14, CD20, CD15, glycophorin A) CD11c ${ }^{+} \mathrm{HLADR}^{+}$ cells (79) and are classified into three groups based on their expression of BDCA1, BDCA3, and CD16 (60). BDCA1 ${ }^{+}\left(\mathrm{CD}^{+} \mathrm{C}^{+}\right)$ DCs are one of the blood DC subsets found, in addition to lymphoid tissue-resident DCs and those observed in the skin of humans (79-81). BACA- ${ }^{+}$DCs are likely the human counter-

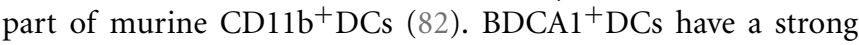
capacity for allostimulation (79) and can cross-present exogenous antigen to $\mathrm{CD}^{+} \mathrm{T}$ cells but less efficiently than $\mathrm{BDCA}^{+} \mathrm{DCs}$ (46-48, 83-85).

\section{CHIMERISM AFTER HUMAN ALLOGENEIC HCT}

Although the replenishment of recipient DCs depends on donor hematopoietic stem cells (HSCs) and associated precursors, the exact half-life of host APCs in especially inflamed tissues is not well-understood. So far, kinetics of DC engraftment and turnover (DC chimerism) utilizing myeloid specific or directly staining DCs in peripheral blood mononuclear cells (PBMCs) after allo-HCT, have been reported in humans (86-99). Most of these reports demonstrated that the reconstitution of human DCs (myeloid CD $11 \mathrm{c}^{+} \mathrm{DCs}$ and plasmacytoid $\mathrm{CD} 123^{+} \mathrm{DCs}$ ) in the early phase of allo-HCT show that nearly complete donor-derived chimerism (CDC) develops and maintains in the late phase. However, a small population of recipient-derived DCs may exist long-term $(86,90$, $93,94)$. Interestingly, patients with acute GVHD showed significantly lower donor chimerism of DCs as well as low numbers of circulating DCs $(93,94,96)$. Further, 6-sulfo lac NAc DCs (slan DCs), potent producers of inflammatory cytokines following LPS stimulation (100) are a major subpopulation of human blood DCs and are also reduced in the patients with severe acute GVHD (92). Although it is helpful to examine the kinetics and chimerism of the peripheral circulating DCs, the kinetics and activation of tissue-resident DC subsets in recipient (especially GVHD-associated organs and/or lymph nodes) might play a role in the development of GVHD.

Host-derived Langerhans cells (LCs) are rapidly depleted by myeloablative regimens and are quickly replaced by donor type in the absence of GVHD. The recovery of donor LC chimerism and numbers, however, are delayed in the presence of acute GVHD $(98,99)$. In the skin, host-derived myeloid DCs (such as CD1a ${ }^{+}$ and $\left.\mathrm{CD} 14^{+} \mathrm{DCs}\right)$ are quickly replaced by donor cells, where hostderived macrophages still exist during GVHD (97). Similar to the relationship between GVHD and DC kinetics, a decrease in number of DCs is observed (96) and mixed chimerism in DCs has the 
capacity for a potent GVT effect in donor lymphocyte infusion (DLI) (101). This suggests a positive impact of host-derived DCs on GVT effect.

\section{DCs AFTER EXPERIMENTAL ALLOGENEIC HCT}

The results from experimental allo-HCT suggest a complicate role for DCs in GVHD. For instance, cDCs and pDCs are activated by TBI $(102)$ and inflammatory cytokines $(103,104)$ (IL-1 and TNF- $\alpha$ ), which are released by damaged tissues. These activation signals up-regulate the expression of antigen presenting and co-stimulatory molecules and could modulate GVHD (102). Moreover, when all other hematopoietic APCs are absent, DCs alone may induce GVHD $(5,105)$. However, recent reports indicate that host-derived hematopoietic APCs are dispensable for inducing GVHD, specifically CD $11 c^{+}$DCs and/or pDCs depletion in the presence of other APCs $(106,107)$ does not attenuate GVHD, it might even increase lethal GVHD $(15,107)$. These data clearly demonstrate that host DCs are therefore not crucial for the induction of GVHD and could even play a regulatory role. On the other hand, donor-derived APCs, especially cDCs too are not required for induction of GVHD, but may play a role in maintenance or aggravation of GVHD in presence of other hematopoietic APCs $(6,106)$.

\section{DCs AND GVT}

To maximize GVT responses, two important factors must be considered: antigen presentation and donor $\mathrm{T}$ cells. Although both host and donor APCs have been shown to play an important role in GVHD, their role in GVT is only beginning to be understood. Donor $\mathrm{T}$ cells have to attack recipient tumor cells in GVT. To that end, they must recognize both alloantigens and tumor specific antigens (TSAs) that presented either directly by the tumor or indirectly by the professional APCs (Figure 1). There is a large amount of evidence that tumor themselves are generally poor presenters and activators of T cell effector responses. In the context of allo-HCT, professional APCs are required for GVT. Their requirement, however, when certain leukemia or tumors may efficiently present antigens to donor T cells have not been obviously analyzed. Nonetheless, GVT responses are optimal when both alloantigens and TSAs responses are induced (7). While alloantigen responses are also elicited by many APCs including both hematopoieticderived and non-hematopoietic-derived APCs cause GVHD, TSAs are exclusively directed to tumors and thus considered to GVT without concomitantly causing GVHD. In cases where tumors are poor APCs of TSAs to donor T cells, the TSAs likely have to be efficiently taken up and cross-presented on professional APCs. In this regard, DCs may be most relevant and could employ three possible mechanisms they possess better than other hematopoietic APCs, capability for better cross-presentation and cross-dressing.

Clinically, most patients with allo-HCT receive HSCs and T cells from human leukocyte antigen (HLA) matched, but multiple minor histocompatibility antigens (MiHAs) mismatched donors. This difference in MiHAs between host and donor are targets for donor T cells to mediate GVH responses. Alloantigen is expressed by all host APC subsets as endogenous antigen, which they directly present to donor $\mathrm{CD}^{+} \mathrm{T}$ cells, even if the interaction is brief (4). In addition to MiHAs, donor T cells respond to TSAs that are virally encoded and/or mutated tumor antigens representing additional important targets for GVT responses. Activated and proliferated allogeneic T cells, stimulated by APCs, are "double edged swords" in that they not only attack host residual tumors but also damage normal host tissues. Augmenting GVT responses through identification of relevant TSAs and determining T cells that specifically respond to them is clinically challenging because GVHD is an allo-reactive disease enhancing TSA-specific T cell responses, which are dependent on allogeneic reactions $(108,109)$. As one approach to distinguish this clinical dilemma, recently, MHC class I-associated tumor-specific phosphopeptides presented on hematological tumors were shown to be critical for induction of their specific memory-like $\mathrm{CD}^{+} \mathrm{T}$ cells against leukemia and that the response against leukemic patients can be restored after allo-HCT (110). These suggest that DCs must simultaneously present both alloantigens, derived primarily from the endogenously polymorphic peptides in the host target tissues, and TSA to donor CD8 ${ }^{+}$ and $\mathrm{CD}^{+}{ }^{+} \mathrm{T}$ cells via MHC class I and class II molecules, respectively. In the clinic, the importance of host APCs in GVL has been suggested in patients with mixed chimerism after DLI in non-myeloablative BMT (111).

We and others have experimentally explored the role of APCs in GVL. Host type APCs are required to maximize GVT responses after allo-HCT (7) and after DLI because they prime donor CTL in an effective manner (112-115). Host MHC class $\mathrm{II}^{+}$ APCs and $\mathrm{CD}^{+} \mathrm{T}$ cells have an indispensable role in CTL responses in mixed chimera models (112). In addition, donor $\mathrm{T}$ cells primed by leukemia lysate-pulsed host APCs before DLI, enhance GVT responses in either leukemia-bearing full chimera or mixed chimera models (113). These data suggest that the host environment is critical for mediating GVT responses. Host type sialoadhesin ${ }^{+}$macrophages, which increase inducible nitric oxide (iNOS) production by CD40-40L interaction in the liver, stimulate CTL and prevent liver metastasis $(116,117)$. Based on the fact that host leukemia cells or tumors express alloantigens, in addition to TSA, may possess co-stimulatory molecules, they could be "APCs." Although they express APC like features, they have likely undergone a process of "immune-modulating," making them poor direct stimulators of an effective $\mathrm{T}$ cell response using a variety of immune-suppressive mechanisms. We have shown that certain lymphoma cells lines, despite some APC features, are not capable of driving an efficient GVT response in the absence of hematopoietic-derived APCs (7).

We have explored, more recently, the APC subsets that are required for optimal GVT without GVHD. We recently found that host-derived $\mathrm{CD} 8 \alpha^{+} \mathrm{DCs}$ are required for the induction of optimal GVT responses utilizing Batf3 deficient mice as recipients in experimental allo-HCT (8). We also found that TLR3 stimulation via poly I:C in host $\mathrm{CD} 8 \alpha^{+} \mathrm{DCs}$, enhanced GVL responses without exacerbating GVHD (8). As we described previously, CD $8 \alpha^{+}$DCs are critical for cross-presentation of tumor and viral antigens $(32,118,119)$ because of their well-specialized crosspresentation capacity and their superior ability to prime antitumor CTL responses $(32,119-121)$ without enhancing GVHD (8, $122)$. As noted above, recently human $\mathrm{BDCA} 3^{+}, \mathrm{XCR}-1^{+}, \mathrm{DNGR}-$ $1^{+}$DCs found in spleen, blood, and non-lymphoid tissues are recognized as the equivalent of murine $\mathrm{CD} 8 \alpha^{+} \mathrm{DCs}$ by multiple 


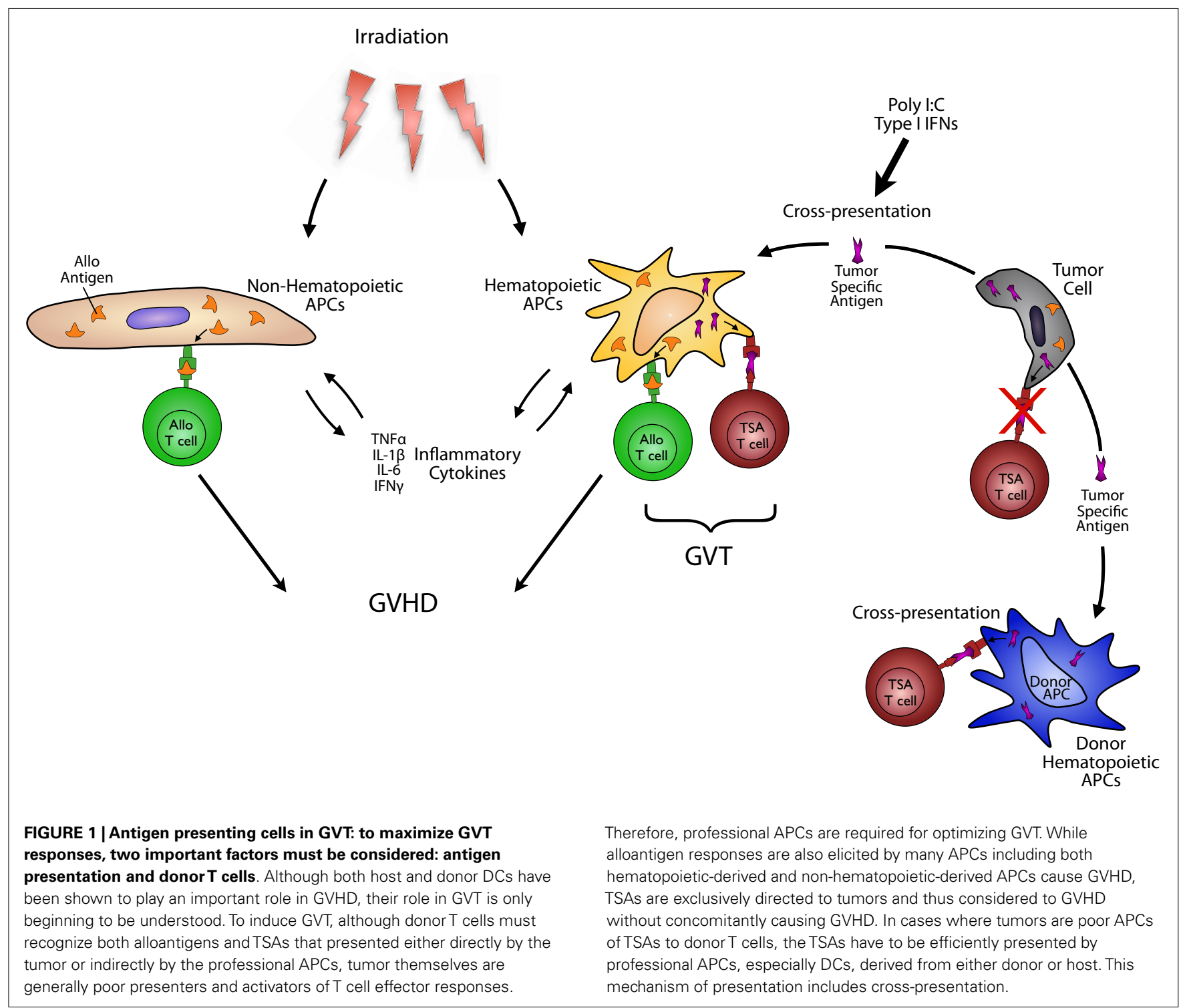

investigators $(26,46-48,123)$. Therefore, our investigations underscore the principle of enhancing antigen presentation using a subset of host APCs as a strategy for effective enhancement of GVT responses following allo-HCT. However, cellular processes of regulating GVT responses in host APCs still remain unclear. Specifically whether low numbers of $\mathrm{CD} 8 \alpha^{+}$DCs reduce TSA responses or decrease GVT responses remain unknown. We also explored the molecular mechanism in hematopoietic-derived APCs for enhancing GVHD. The absence of Ikaros in host hematopoietic APCs exacerbates GVHD, but without concomitantly enhancing GVT responses in multiple models (unpublished data). This uncoupling is an interesting phenomenon as GVT responses are usually tightly linked with GVHD severity. Furthermore, genetic alteration of Ikaros family zinc finger protein 1 (IKZF1) in acute lymphoblastic leukemia (ALL) is associated with poor outcome and high relapse after chemotherapy $(124,125)$. Therefore, we are pursuing whether Ikaros in leukemic cells alone or both leukemic and non-leukemic host hematopoietic cells play a role in mediating GVT resistance.
Understanding the host microenvironment, especially that of the tumor is essential for GVT studies. Tumor-infiltrating DCs in tumor microenvironments in hosts are suggested to regulate CTL responses, however, their role in the context of allogeneic HCT remain obscure.

The role of donor-derived DCs in mediating GVT is also being explored. Initial reports regarding this association demonstrated that donor APCs are not required for GVT responses, but play an indispensable role in GVHD in MHC matched, MiHA mismatched BMT model (6). In order to present host TSAs via donor APCs to donor $\mathrm{CD}^{+} \mathrm{T}$ cells, donor APCs must have the capacity for crosspresentation as they do not express both endogenous alloantigens and TSAs. Furthermore, additional studies are needed to determine which specific subsets of donor APCs play a critical role in enhancing GVT responses. Reports suggest that donor CD11bAPCs within the BM grafts consist mostly of $\mathrm{pDC}$ progenitors (pre-pDCs) and enhance GVT activity of donor T cells by promoting differentiation into Th1/type 1 CTLs. These effects have further 
been shown to be mediated by IL-12 in murine allo-HCT models $(126,127)$. Pre-pDCs also regulate GVH and GVT responses altering the balance between donor Tregs and inflammatory $\mathrm{T}$ cells by inducing indoleamine 2,3-dioxygenase (IDO) synthesis (128). In humans, however, there are no data of the exact mechanisms of specific subsets of donor APCs in GVT. Therefore, studies examining and elucidating the kinetics of these subsets of DCs would contribute to likely better understanding the mechanism of GVT in humans.

Recent reports suggest a paradoxical association between CMV reactivation after allo-HCT and reduced disease relapse (129-131). The mechanisms that CMV reactivation induces potent GVT are still unclear. However, donor APCs and NK cells might play an important role in this interesting phenomenon (132). Interaction between cDCs and NK cells is critical to the activation of effective antiviral or antitumor response $(133,134)$. It is possible that donor DC-NK cell interactions might play a role in enhancing GVT mediated by NK cells in this context.

\section{CROSS-PRESENTATION AND GVT}

Dendritic cells are well-known to take up exogenous antigens via endocytosis or phagocytosis. Antigen is then processed in the endoplasmic reticulum (ER) and presented via Class I molecules. These processes are known as cross-presentation. Although the molecular mechanism of cross-presentation is still under investigation, two major intracellular pathways of cross-presentation are speculated. One is cytosolic and the other one is a vacuolar pathway (135). The cytosolic pathway depends on the proteasome, which degrades internalized proteins in the cytosol. The degraded peptides are then transported into the ER in a transporter associated with antigen processing 1 (TAP1) and TAP2-dependent manner. Peptide is then either loaded onto MHC class I molecules (ER loading) or re-imported into the phagosome to be loaded onto $\mathrm{MHC}$ class I molecules (phagosomal reloading) (135). A novel molecular mechanism utilizing the small GTPases Rac1 (CD8 $\alpha^{-}$DCs) and $\operatorname{Rac} 2\left(\mathrm{CD} 8 \alpha^{+} \mathrm{DCs}\right)$, regulate phagosomal oxidation, which is critical for the cross-presentation capacity (136). In addition, soluble $N$-ethylmaleimide-sensitive factor attachment protein receptor (SNARE) Sec22b plays an important role in phagosomal function through the recruitment of ER proteins into the phagosome (137) and heat shock protein 90 (HSP90) contributes to cytosolic translocation of extracellular antigen, enhancing crosspresentation (138). Conversely, the vacuolar pathway is known to be a TAP and proteasome independent pathway (139-141) where exogenous antigens are degraded in the phagosome and subsequently loaded on MHC class I. This pathway is sensitive to cathep$\sin \mathrm{S}$ inhibitors (140). Some DCs, such as those that express CD $8 \alpha^{+}$ $(32,37,142,143), \mathrm{CD} 103^{+}(144-147)$ in mice, and BDCA3 ${ }^{+} \mathrm{DCs}$ (functional homology to mice CD8 $\alpha^{+}$DCs) $(46,123,148-150)$ in human are known to have the capacity for cross-presentation. However, some recent reports suggested that nearly all DCs have the capacity for cross-presentation depending on the source of antigen, cytokine milieu, and expression of immunoreceptors specialized to take up exogenous antigens $(76,83,149,151)$. The role of cross-presentation in GVT responses is still unknown. Our data indicates a role for $\mathrm{CD} 8 \alpha^{+} \mathrm{DCs}$ and also suggested that TLR3 agonist, polyI:C, can increase GVT without enhancing
GVHD in host DC-dependent manner (8). Therefore, we presume that specialized DCs could be associated with optimizing GVT responses because mouse $\mathrm{CD} 8 \alpha^{+} \mathrm{DCs}$ and human $\mathrm{BDCA} 3^{+} \mathrm{DCs}$ possess the most potent cross-presentation capacity of TSAs. However, direct in vivo demonstration enhancing cross-presentation by CD $8 \alpha^{+}$DCs or TLR3 agonist in increasing GVT has not been shown. While these are being explored, at the minimum our data suggested a novel concept that it is feasible to modulate host DCs to improve GVT without increasing toxicity. It remains to be tested, however, whether this concept holds true for all leukemia or tumors. In any event, it does suggest a window of opportunity for careful design of clinical trials in high-risk leukemia.

\section{CROSS-DRESSING AND GVL}

Recently, another means of antigen presentation, called "crossdressing" was forward by Ostrand-Rosenberg's group in 2006 (152, $153)$. It is postulated that cross-dressing transfers cellular materials (such as peptide MHC to DCs) triggering DC activation and enhanced tumor-specific CD4 ${ }^{+} \mathrm{T}$ cells in cancer vaccine (153). In 2011, as a breakthrough mechanism of elicited CTL responses by DCs, preformed peptide MHC class I complex is expressed on infected cells and can be transferred to uninfected DCs without requiring other antigen processing. This process mediates the activation of memory CD8 ${ }^{+} \mathrm{T}$ cells after viral infection (154). $\mathrm{CD} 8 \alpha^{+} \mathrm{CD}_{103}{ }^{+} \mathrm{DCs}$ are thought to play an important role in not only cross-presentation but also cross-dressing to prime CTLs following vaccination (155). Its role suggested in GVHD but GVT responses is still unknown.

\section{THE STRATEGY OF AUGMENTING GVT RESPONSES UTILIZING DCs}

Graft-versus-tumor is tightly linked with GVHD and is very difficult to uncouple the two. However, recent advances and understanding of DC biology make treatment regimens previously not considered, namely modulating antigen presentation, to now be practical options. Nonetheless much remains to be understood. Specifically, comprehensive understanding of DC subsets will enable us to maximize GVT responses. For instance, either by enhancement of cross-presentation, increased NK cell activation, or induction of type I IFN etc.

We and others have shown that administration of poly I:C stimulates TLR 3 on $\mathrm{CD} 8 \alpha^{+}$DCs enhancing cross-presentation and direct presentation to CTLs against tumors and virus infection $(8,118)$. In addition, poly I:C administration also activates NK cells through the enhancement of myeloid DC-NK interaction mediated through an IRF-3-toll/interleukin 1 receptor homology domain-containing adaptor molecule (TICAM-1)-IRF-3dependent NK-activating molecule (INAM) axis-dependent manner (134). Moreover, CD $8 \alpha^{+}$DCs treated by poly I:C can activate NK cells in the IFN-promoter stimulator-1 (IPS-1) and Toll/IL-1R domain-containing adaptor inducing IFN- $\beta$ (TRIF)-dependent manner (156). Therefore, poly I:C treatment after allo-HCT could be extended to increase GVT, however, poly I:C in this context must be carefully studied as it may enhance GVHD.

Careful utilization of exogenous type I IFN (IFN- $\alpha / \beta)$ administration may also be a valuable method of enhancing GVT responses because they play an important role 
in cross-presentation of tumor antigens on DCs, especially CD8 $\alpha^{+}$DCs, and enhance CTL responses $(119,120,157)$. In murine allo-HCT models, exogenous type I IFN administration augments CTL responses through the increased sensitivity of host target tissues and leukemia to respond to cell mediated cytotoxicity in CD8-dependent GVHD/GVT model regardless of decreasing GVHD response in CD4-dependent model (158).

Other strategies to enhance antitumor responses through the augmentation of the cross-presentation capacity of TSA and activation of CTLs may also be feasible. Alpha-alumina nanoparticles (159), poly ( $\gamma$-glutamic acid)-based nanoparticles ( $\gamma$-PGA NPs) (160), Fcgamma-receptor (Fc $\gamma \mathrm{R})$ antigen targeting (161), TLR7 stimulation by polyuridylic acid (polyU), which is a synthetic ssRNA analog (162), vitamin E analog- $\alpha$-tocopheryl oxyacetic acid ( $\alpha$-TEA) (163) may be useful, but have not been studied in GVT models. Modulation of host type DCs with anti-CD3 pre-conditioning is also an efficient strategy for separating GVT and GVHD (164). Furthermore, recent modulation of DCs by reagent-based inducible or constitutive methods suggested that deep deletion of host $\mathrm{cDCs}, \mathrm{pDCs}$, and $\mathrm{B}$ cells are dispensable for decreased GVH responses (107). This indicated that very low numbers of DCs, or all host cells including non-hematopoietic APCs, can directly present alloantigen. Alloantigen expression on host non-hematopoietic cells decreases GVT responses in a PD1/PD-L1-dependent manner in murine experimental BMT (165). Given this, enhancement of function in only certain DCs specialized for TSA presentation may also increase GVT responses without exacerbating GVHD. Moreover, experimental data suggested that modulation of DC function with HDAC inhibitor can result in immunomodulation to reduce GVHD (166).

Aside from enhancement of the presentation capacity in DCs, disruption of negative regulatory interactions is also important for GVT responses. PD-1/PD-L1 interactions and CD47-SIRP- $\alpha$ interactions are thought to be critical immunosuppressive function in the tumor environment. For instance, because the expression of PD-1 on T cells and PD-L1 on APCs facilitated increased Tregs and decreased CTL functions, PD-1/PD-L1 blockade with anti-PD-L1 monoclonal antibody decreased the infiltrating number of Tregs and increased the number and function of tumor reacting CTLs in an AML mouse model (167). Furthermore, knock down of PD-L1 and PD-L2 on MoDCs by utilizing siRNA demonstrated augmented expansion and function of MiHA-specific memory and effector $\mathrm{CD} 8^{+} \mathrm{T}$ cells from leukemia patients in vitro (168). These data suggested that anti-PD-L1 and PD-L2 blockade might be a potential strategy for the enhancement of GVT responses. Tumors may also escape from tumor surveillance utilizing the interaction between monocytic CD47 and SIRP- $\alpha$, which is an inhibitory receptor of phagocytosis (169). Recent report showed engineered high affinity SIRP- $\alpha$ variants can disrupt this interaction and increase phagocytosis of cancer cells and enhance antitumor response (170). Although we do not know how these pathways affect GVHD, such strategy may also be considered as potential option to treat patients with high risk leukemias.

\section{CLOSING REMARKS}

Dendritic cells play important roles in both GVHD and GVT. Because DCs are heterogeneous, the role of specific DCs in GVHD and GVT in the presence or absence of other hematopoieticderived APCs will need further examination. Identification of a specialized subtype of DC that may increase GVT without enhancing GVHD, such as CD $8 \alpha^{+}$DCs in mice, may be possible. Functional studies have identified direct antigen presentation capacity, cross-presentation, and cross-priming of CTLs as critical mechanisms in allo-HCT. To enhance GVT response, both alloantigen and TSA must be presented to CTLs. However, tumor cells themselves have a poor antigen presentation capacity, therefore TSA are cross-presented by APCs. Enhancement of the cross-presentation capacity has the potential to increase GVT response and be a presumably new strategy in allo-HCT. Through the utilization of DCs, the goal of increasing GVT and diminishing GVHD might be realized.

\section{REFERENCES}

1. Blazar BR, Murphy WJ, Abedi M. Advances in graft-versus-host disease biology and therapy. Nat Rev Immunol (2012) 12:443-58. doi:10.1038/nri3212

2. Ferrara JL, Levine JE, Reddy P, Holler E. Graft-versus-host disease. Lancet (2009) 373:1550-61. doi:10.1016/S0140-6736(09)60237-3

3. Shlomchik WD. Graft-versus-host disease. Nat Rev Immunol (2007) 7:340-52. doi:10.1038/nri2000

4. Shlomchik WD, Couzens MS, Tang CB, McNiff J, Robert ME, Liu J, et al. Prevention of graft versus host disease by inactivation of host antigen-presenting cells. Science (1999) 285:412-5. doi:10.1126/science.285.5426.412

5. Teshima T, Ordemann R, Reddy P, Gagin S, Liu C, Cooke KR, et al. Acute graftversus-host disease does not require alloantigen expression on host epithelium. Nat Med (2002) 8:575-81. doi:10.1038/nm0602-575

6. Matte CC, Liu J, Cormier J, Anderson BE, Athanasiadis I, Jain D, et al. Donor APCs are required for maximal GVHD but not for GVL. Nat Med (2004) 10:987-92. doi:10.1038/nm1089

7. Reddy P, Maeda Y, Liu C, Krijanovski OI, Korngold R, Ferrara JL. A crucial role for antigen-presenting cells and alloantigen expression in graft-versusleukemia responses. Nat Med (2005) 11:1244-9. doi:10.1038/nm1309

8. Toubai T, Sun Y, Luker G, Liu J, Luker KE, Tawara I, et al. Host-derived CD8+ dendritic cells are required for induction of optimal graft-versus-tumor responses after experimental allogeneic bone marrow transplantation. Blood (2013) 121:4231-41. doi:10.1182/blood-2012-05-432872

9. Helft J, Ginhoux F, Bogunovic M, Merad M. Origin and functional heterogeneity of non-lymphoid tissue dendritic cells in mice. Immunol Rev (2010) 234:55-75. doi:10.1111/j.0105-2896.2009.00885.x

10. Haniffa M, Collin M, Ginhoux F. Ontogeny and functional specialization of dendritic cells in human and mouse. Adv Immunol (2013) 120:1-49. doi:10.1016/B978-0-12-417028-5.00001-6

11. Vremec D, Zorbas M, Scollay R, Saunders DJ, Ardavin CF, Wu L, et al. The surface phenotype of dendritic cells purified from mouse thymus and spleen: investigation of the CD8 expression by a subpopulation of dendritic cells. J Exp Med (1992) 176:47-58. doi:10.1084/jem.176.1.47

12. Vremec D, Pooley J, Hochrein H, Wu L, Shortman K. CD4 and CD8 expression by dendritic cell subtypes in mouse thymus and spleen. J Immunol (2000) 164:2978-86.

13. Shortman K, Heath WR. The CD8+ dendritic cell subset. Immunol Rev (2010) 234:18-31. doi:10.1111/j.0105-2896.2009.00870.x

14. Toubai T, Tawara I, Sun Y, Liu C, Nieves E, Evers R, et al. Induction of acute GVHD by sex-mismatched H-Y antigens in the absence of functional radiosensitive host hematopoietic-derived antigen-presenting cells. Blood (2012) 119:3844-53. doi:10.1182/blood-2011-10-384057

15. Koyama M, Kuns RD, Olver SD, Raffelt NC, Wilson YA, Don AL, et al. Recipient nonhematopoietic antigen-presenting cells are sufficient to induce lethal acute graft-versus-host disease. Nat Med (2012) 18:135-42. doi:10.1038/nm.2597

16. Wang X, Li H, Matte-Martone C, Cui W, Li N, Tan HS, et al. Mechanisms of antigen presentation to $\mathrm{T}$ cells in murine graft-versus-host disease: cross-presentation and the appearance of cross-presentation. Blood (2011) 118:6426-37. doi:10.1182/blood-2011-06-358747

17. Merad M, Sathe P, Helft J, Miller J, Mortha A. The dendritic cell lineage: ontogeny and function of dendritic cells and their subsets in the steady state 
and the inflamed setting. Annu Rev Immunol (2013) 31:563-604. doi:10.1146/ annurev-immunol-020711-074950

18. Reizis B, Bunin A, Ghosh HS, Lewis KL, Sisirak V. Plasmacytoid dendritic cells: recent progress and open questions. Annu Rev Immunol (2011) 29:163-83. doi:10.1146/annurev-immunol-031210-101345

19. Dominguez PM, Ardavin C. Differentiation and function of mouse monocytederived dendritic cells in steady state and inflammation. Immunol Rev (2010) 234:90-104. doi:10.1111/j.0105-2896.2009.00876.x

20. Wilson NS, El-Sukkari D, Belz GT, Smith CM, Steptoe RJ, Heath WR, et al. Most lymphoid organ dendritic cell types are phenotypically and functionally immature. Blood (2003) 102:2187-94. doi:10.1182/blood-2003-020513

21. Toubai T, Sun Y, Tawara I, Friedman A, Liu C, Evers R, et al. Ikaros-Notch axis in host hematopoietic cells regulates experimental graft-versus-host disease. Blood (2011) 118:192-204. doi:10.1182/blood-2010-12-324616

22. Sancho D, Mourão-Sá D, Joffre OP, Schulz O, Rogers NC, Pennington DJ, et al. Tumor therapy in mice via antigen targeting to a novel, DC-restricted C-type lectin. J Clin Invest (2008) 118:2098-110. doi:10.1172/JCI34584

23. Edwards AD, Diebold SS, Slack EM, Tomizawa H, Hemmi H, Kaisho T, et al Toll-like receptor expression in murine DC subsets: lack of TLR7 expression by CD8 alpha+ DC correlates with unresponsiveness to imidazoquinolines. Eur J Immunol (2003) 33(4):827-33. doi:10.1002/eji.200323797

24. Albert ML, Pearce SF, Francisco LM, Sauter B, Roy P, Silverstein RL, et al. Immature dendritic cells phagocytose apoptotic cells via alphavbeta5 and CD36, and cross-present antigens to cytotoxic T lymphocytes. J Exp Med (1998) 188:1359-68. doi:10.1084/jem.188.7.1359

25. Dorner BG, Dorner MB, Zhou X, Opitz C, Mora A, Güttler S, et al. Selective expression of the chemokine receptor XCR1 on cross-presenting dendritic cells determines cooperation with CD8+ T cells. Immunity (2009) 31:823-33. doi:10.1016/j.immuni.2009.08.027

26. Poulin LF, Reyal Y, Uronen-Hansson H, Schraml BU, Sancho D, Murphy KM, et al. DNGR-1 is a specific and universal marker of mouse and human Batf3dependent dendritic cells in lymphoid and nonlymphoid tissues. Blood (2012) 119:6052-62. doi:10.1182/blood-2012-01-406967

27. Maraskovsky E, Brasel K, Teepe M, Roux ER, Lyman SD, Shortman K, et al. Dramatic increase in the numbers of functionally mature dendritic cells in Flt3 ligand-treated mice: multiple dendritic cell subpopulations identified. J Exp Med (1996) 184:1953-62. doi:10.1084/jem.184.5.1953

28. Teshima T, Reddy P, Lowler KP, KuKuruga MA, Liu C, Cooke KR, et al Flt3 ligand therapy for recipients of allogeneic bone marrow transplants expands host CD8 alpha(+) dendritic cells and reduces experimental acute graft-versus-host disease. Blood (2002) 99:1825-32. doi:10.1182/blood. V99.5.1825

29. Aliberti J, Schulz O, Pennington DJ, Tsujimura H, Reis e Sousa C, Ozato $\mathrm{K}$, et al. Essential role for ICSBP in the in vivo development of murine CD8alpha + dendritic cells. Blood (2003) 101:305-10. doi:10.1182/blood2002-04- 1088

30. Schiavoni G, Mattei F, Sestili P, Borghi P, Venditti M, Morse HC III, et al. ICSBP is essential for the development of mouse type I interferon-producing cells and for the generation and activation of CD8alpha(+) dendritic cells. J Exp Med (2002) 196:1415-25. doi:10.1084/jem.20021263

31. Hacker C, Kirsch RD, Ju XS, Hieronymus T, Gust TC, Kuhl C, et al. Transcriptional profiling identifies Id 2 function in dendritic cell development. Nat Immunol (2003) 4:380-6. doi:10.1038/ni903

32. Hildner K, Edelson BT, Purtha WE, Diamond M, Matsushita H, Kohyama M, et al. Batf3 deficiency reveals a critical role for CD8alpha+ dendritic cells in cytotoxic T cell immunity. Science (2008) 322:1097-100. doi:10.1126/science. 1164206

33. Kashiwada M, Pham NL, Pewe LL, Harty JT, Rothman PB. NFIL3/E4BP4 is a key transcription factor for CD8alpha(+) dendritic cell development. Blood (2011) 117:6193-7. doi:10.1182/blood-2010-07-295873

34. Guerriero A, Langmuir PB, Spain LM, Scott EW. PU.1 is required for myeloid-derived but not lymphoid-derived dendritic cells. Blood (2000) 95 879-85.

35. Meredith MM, Liu K, Kamphorst AO, Idoyaga J, Yamane A, Guermonprez P, et al. Zinc finger transcription factor $\mathrm{zDC}$ is a negative regulator required to prevent activation of classical dendritic cells in the steady state. J Exp Med (2012) 209:1583-93. doi:10.1084/jem.20121003
36. Jackson JT, Hu Y, Liu R, Masson F, D’Amico A, Carotta S, et al. Id2 expression delineates differential checkpoints in the genetic program of CD8alpha+ and CD103+ dendritic cell lineages. EMBO J (2011) 30:2690-704. doi:10.1038/ emboj.2011.163

37. den Haan JM, Lehar SM, Bevan MJ. CD8(+) but not CD8(-) dendritic cells cross-prime cytotoxic T cells in vivo. J Exp Med (2000) 192:1685-96. doi:10.1084/jem.192.12.1685

38. Reis e Sousa C, Hieny S, Scharton-Kersten T, Jankovic D, Charest H, Germain $\mathrm{RN}$, et al. In vivo microbial stimulation induces rapid CD40 ligandindependent production of interleukin 12 by dendritic cells and their redistribution to T cell areas. J Exp Med (1997) 186:1819-29. doi:10.1084/jem.186.11. 1819

39. Maldonado-López R, De Smedt T, Michel P, Godfroid J, Pajak B, Heirman $\mathrm{C}$, et al. CD8alpha+ and CD8alpha- subclasses of dendritic cells direct the development of distinct T helper cells in vivo. J Exp Med (1999) 189:587-92. doi:10.1084/jem.189.3.587

40. Toubai T, Malter C, Tawara I, Liu C, Nieves E, Lowler KP, et al. Immunization with host-type CD8\{alpha\}+ dendritic cells reduces experimental acute GVHD in an IL-10-dependent manner. Blood (2010) 115:724-35. doi:10.1182/blood-2009-06-229708

41. Yamazaki S, Dudziak D, Heidkamp GF, Fiorese C, Bonito AJ, Inaba K, et al. CD8+ CD205+ splenic dendritic cells are specialized to induce Foxp3+ regulatory T cells. J Immunol (2008) 181:6923-33.

42. Belz GT, Behrens GM, Smith CM, Miller JF, Jones C, Lejon K, et al. The CD8alpha(+) dendritic cell is responsible for inducing peripheral self-tolerance to tissue-associated antigens. J Exp Med (2002) 196:1099-104. doi:10.1084/ jem.20020861

43. Bonifaz L, Bonnyay D, Mahnke K, Rivera M, Nussenzweig MC, Steinman RM. Efficient targeting of protein antigen to the dendritic cell receptor DEC-205 in the steady state leads to antigen presentation on major histocompatibility complex class I products and peripheral CD8+ T cell tolerance. J Exp Med (2002) 196:1627-38. doi:10.1084/jem.20021598

44. Kretschmer K, Apostolou I, Hawiger D, Khazaie K, Nussenzweig MC, von Boehmer $\mathrm{H}$. Inducing and expanding regulatory $\mathrm{T}$ cell populations by foreign antigen. Nat Immunol (2005) 6:1219-27. doi:10.1038/ni1265

45. Luckey U, Maurer M, Schmidt T, Lorenz N, Seebach B, Metz M, et al. T cell killing by tolerogenic dendritic cells protects mice from allergy. J Clin Invest (2011) 121:3860-71. doi:10.1172/JCI45963

46. Bachem A, Güttler S, Hartung E, Ebstein F, Schaefer M, Tannert A, et al. Superior antigen cross-presentation and XCR1 expression define human CD11c+CD141+ cells as homologues of mouse CD8+ dendritic cells. J Exp Med (2010) 207:1273-81. doi:10.1084/jem.20100348

47. Crozat K, Guiton R, Contreras V, Feuillet V, Dutertre CA, Ventre E, et al. The XC chemokine receptor 1 is a conserved selective marker of mammalian cells homologous to mouse CD8alpha+ dendritic cells. J Exp Med (2010) 207:1283-92. doi:10.1084/jem.20100223

48. Jongbloed SL, Kassianos AJ, McDonald KJ, Clark GJ, Ju X, Angel CE, et al. Human CD141+ (BDCA-3)+ dendritic cells (DCs) represent a unique myeloid DC subset that cross-presents necrotic cell antigens. J Exp Med (2010) 207:1247-60. doi:10.1084/jem.20092140

49. Huysamen C, Willment JA, Dennehy KM, Brown GD. CLEC9A is a novel activation C-type lectin-like receptor expressed on BDCA3+ dendritic cells and a subset of monocytes. J Biol Chem (2008) 283:16693-701. doi:10.1074/jbc. M709923200

50. Meixlsperger S, Leung CS, Rämer PC, Pack M, Vanoaica LD, Breton G, et al. CD141+ dendritic cells produce prominent amounts of IFN-alpha after dsRNA recognition and can be targeted via DEC-205 in humanized mice. Blood (2013) 121:5034-44. doi:10.1182/blood-2012-12-473413

51. Caminschi I, Lucas KM, O’Keeffe MA, Hochrein H, Laâbi Y, Brodnicki TC, et al. Molecular cloning of a C-type lectin superfamily protein differentially expressed by CD8alpha(-) splenic dendritic cells. Mol Immunol (2001) 38:365-73. doi:10.1016/S0161-5890(01)00067-0

52. Lahoud MH, Proietto AI, Gartlan KH, Kitsoulis S, Curtis J, Wettenhall J, et al. Signal regulatory protein molecules are differentially expressed by CD8- dendritic cells. J Immunol (2006) 177:372-82.

53. Dudziak D, Kamphorst AO, Heidkamp GF, Buchholz VR, Trumpfheller C, Yamazaki S, et al. Differential antigen processing by dendritic cell subsets in vivo. Science (2007) 315:107-11. doi:10.1126/science.1136080 
54. Backer R, van Leeuwen F, Kraal G, den Haan JM. CD8 - dendritic cells preferentially cross-present Saccharomyces cerevisiae antigens. Eur J Immunol (2008) 38:370-80. doi:10.1002/eji.200737647

55. Caton ML, Smith-Raska MR, Reizis B. Notch-RBP-J signaling controls the homeostasis of CD8- dendritic cells in the spleen. J Exp Med (2007) 204:1653-64. doi:10.1084/jem.20062648

56. Lewis KL, Caton ML, Bogunovic M, Greter M, Grajkowska LT, Ng D, et al Notch2 receptor signaling controls functional differentiation of dendritic cells in the spleen and intestine. Immunity (2011) 35:780-91. doi:10.1016/j.immuni. 2011.08.013

57. Satpathy AT, Briseño CG, Lee JS, Ng D, Manieri NA, Kc W, et al. Notch2dependent classical dendritic cells orchestrate intestinal immunity to attachingand-effacing bacterial pathogens. Nat Immunol (2013) 14:937-48. doi:10.1038/ ni.2679

58. MacDonald AS, Straw AD, Bauman B, Pearce EJ. CD8 - dendritic cell activation status plays an integral role in influencing Th2 response development. J Immunol (2001) 167:1982-8.

59. Huang LY, Reis e Sousa C, Itoh Y, Inman J, Scott DE. IL-12 induction by a TH1-inducing adjuvant in vivo: dendritic cell subsets and regulation by IL-10. J Immunol (2001) 167:1423-30.

60. Dzionek A, Fuchs A, Schmidt P, Cremer S, Zysk M, Miltenyi S, et al. BDCA-2, BDCA-3, and BDCA-4: three markers for distinct subsets of dendritic cells in human peripheral blood. J Immunol (2000) 165:6037-46.

61. Meyer-Wentrup F, Benitez-Ribas D, Tacken PJ, Punt CJ, Figdor CG, de Vries IJ, et al. Targeting DCIR on human plasmacytoid dendritic cells results in antigen presentation and inhibits IFN-alpha production. Blood (2008) 111:4245-53. doi:10.1182/blood-2007-03-081398

62. Asselin-Paturel C, Boonstra A, Dalod M, Durand I, Yessaad N, DezutterDambuyant C, et al. Mouse type I IFN-producing cells are immature APCs with plasmacytoid morphology. Nat Immunol (2001) 2:1144-50. doi:10.1038/ni736

63. O'Keeffe M, Hochrein H, Vremec D, Caminschi I, Miller JL, Anders EM, et al. Mouse plasmacytoid cells: long-lived cells, heterogeneous in surface phenotype and function, that differentiate into CD8(+) dendritic cells only after microbial stimulus. J Exp Med (2002) 196:1307-19. doi:10.1084/jem.20021031

64. Olweus J, BitMansour A, Warnke R, Thompson PA, Carballido J, Picker LJ, et al. Dendritic cell ontogeny: a human dendritic cell lineage of myeloid origin. Proc Natl Acad Sci U S A (1997) 94:12551-6. doi:10.1073/pnas.94.23.12551

65. Manfra DJ, Chen SC, Jensen KK, Fine JS, Wiekowski MT, Lira SA. Conditional expression of murine Flt3 ligand leads to expansion of multiple dendritic cell subsets in peripheral blood and tissues of transgenic mice. J Immunol (2003) 170:2843-52.

66. Laouar Y, Welte T, Fu XY, Flavell RA. STAT3 is required for Flt3L-dependent dendritic cell differentiation. Immunity (2003) 19:903-12. doi:10.1016/S10747613(03)00332-7

67. Weigert A, Weichand B, Sekar D, Sha W, Hahn C, Mora J, et al. HIF-1alpha is a negative regulator of plasmacytoid DC development in vitro and in vivo. Blood (2012) 120:3001-6. doi:10.1182/blood-2012-03-417022

68. Allman D, Dalod M, Asselin-Paturel C, Delale T, Robbins SH, Trinchieri G, et al. Ikaros is required for plasmacytoid dendritic cell differentiation. Blood (2006) 108:4025-34. doi:10.1182/blood-2006-03-007757

69. Koyama M, Hashimoto D, Aoyama K, Matsuoka K, Karube K, Niiro H, et al. Plasmacytoid dendritic cells prime alloreactive $\mathrm{T}$ cells to mediate graftversus-host disease as antigen-presenting cells. Blood (2009) 113:2088-95. doi:10.1182/blood-2008-07-168609

70. Banovic T, Markey KA, Kuns RD, Olver SD, Raffelt NC, Don AL, et al. Graftversus-host disease prevents the maturation of plasmacytoid dendritic cells. J Immunol (2009) 182:912-20. doi:10.4049/jimmunol.0990010

71. Segura E, Albiston AL, Wicks IP, Chai SY, Villadangos JA. Different crosspresentation pathways in steady-state and inflammatory dendritic cells. Proc Natl Acad Sci U S A (2009) 106:20377-81. doi:10.1073/pnas.0910295106

72. Segura E, Amigorena S. Inflammatory dendritic cells in mice and humans. Trends Immunol (2013) 34:440-5. doi:10.1016/j.it.2013.06.001

73. Bogunovic M, Ginhoux F, Helft J, Shang L, Hashimoto D, Greter M, et al. Origin of the lamina propria dendritic cell network. Immunity (2009) 31:513-25. doi:10.1016/j.immuni.2009.08.010

74. Varol C, Vallon-Eberhard A, Elinav E, Aychek T, Shapira Y, Luche H, et al. Intestinal lamina propria dendritic cell subsets have different origin and functions. Immunity (2009) 31:502-12. doi:10.1016/j.immuni.2009.06.025
75. Schreurs MW, Eggert AA, de Boer AJ, Figdor CG, Adema GJ. Generation and functional characterization of mouse monocyte-derived dendritic cells. Eur J Immunol (1999) 29:2835-41. doi:10.1002/(SICI)1521-4141(199909)29: $09<2835:: A I D-I M M U 2835>3.3 . C O ; 2-H$

76. Nierkens S, Tel J, Janssen E, Adema GJ. Antigen cross-presentation by dendritic cell subsets: one general or all sergeants? Trends Immunol (2013) 34:361-70. doi:10.1016/j.it.2013.02.007

77. Serbina NV, Pamer EG. Monocyte emigration from bone marrow during bacterial infection requires signals mediated by chemokine receptor CCR2. Nat Immunol (2006) 7:311-7. doi:10.1038/ni1309

78. Serbina NV, Kuziel W, Flavell R, Akira S, Rollins B, Pamer EG. Sequential MyD88-independent and -dependent activation of innate immune responses to intracellular bacterial infection. Immunity (2003) 19:891-901. doi:10.1016/ S1074-7613(03)00330-3

79. MacDonald KP, Munster DJ, Clark GJ, Dzionek A, Schmitz J, Hart DN. Characterization of human blood dendritic cell subsets. Blood (2002) 100:4512-20. doi:10.1182/blood-2001-11-0097

80. Zaba LC, Fuentes-Duculan J, Steinman RM, Krueger JG, Lowes MA. Normal human dermis contains distinct populations of CD11c+BDCA-1+ dendritic cells and CD163+FXIIIA+ macrophages. J Clin Invest (2007) 117:2517-25. doi:10.1172/JCI32282

81. McIlroy D, Troadec C, Grassi F, Samri A, Barrou B, Autran B, et al. Investigation of human spleen dendritic cell phenotype and distribution reveals evidence of in vivo activation in a subset of organ donors. Blood (2001) 97:3470-7. doi:10.1182/blood.V97.11.3470

82. Crozat K, Guiton R, Guilliams M, Henri S, Baranek T, Schwartz-Cornil I, et al. Comparative genomics as a tool to reveal functional equivalences between human and mouse dendritic cell subsets. Immunol Rev (2010) 234:177-98. doi:10.1111/j.0105-2896.2009.00868.x

83. Nizzoli G, Krietsch J, Weick A, Steinfelder S, Facciotti F, Gruarin P, et al. Human CD1c+ dendritic cells secrete high levels of IL-12 and potently prime cytotoxic T-cell responses. Blood (2013) 122:932-42. doi:10.1182/blood-2013-04495424

84. Segura E, Valladeau-Guilemond J, Donnadieu MH, Sastre-Garau X, Soumelis $\mathrm{V}$, Amigorena S. Characterization of resident and migratory dendritic cells in human lymph nodes. J Exp Med (2012) 209:653-60. doi:10.1084/jem.20111457

85. Mittag D, Proietto AI, Loudovaris T, Mannering SI, Vremec D, Shortman K, et al. Human dendritic cell subsets from spleen and blood are similar in phenotype and function but modified by donor health status. J Immunol (2011) 186:6207-17. doi:10.4049/jimmunol.1002632

86. Auffermann-Gretzinger S, Lossos IS, Vayntrub TA, Leong W, Grumet FC, Blume KG, et al. Rapid establishment of dendritic cell chimerism in allogeneic hematopoietic cell transplant recipients. Blood (2002) 99:1442-8. doi:10.1182/blood.V99.4.1442

87. Niiya H, Kanda Y, Saito T, Ohnishi T, Kanai S, Kawano Y, et al. Early full donor myeloid chimerism after reduced-intensity stem cell transplantation using a combination of fludarabine and busulfan. Haematologica (2001) 86:1071-4.

88. Miura Y, Tanaka J, Toubai T, Tsutsumi Y, Kato N, Hirate D, et al. Analysis of donor-type chimerism in lineage-specific cell populations after allogeneic myeloablative and non-myeloablative stem cell transplantation. Bone Marrow Transplant (2006) 37:837-43. doi:10.1038/sj.bmt.1705352

89. Watanabe N, Takahashi S, Ishige M, Ishii Y, Ooi J, Tomonari A, et al. Recipientderived cells after cord blood transplantation: dynamics elucidated by multicolor FACS, reflecting graft failure and relapse. Biol Blood Marrow Transplant (2008) 14:693-701. doi:10.1016/j.bbmt.2008.04.001

90. Boeck S, Hamann M, Pihusch V, Heller T, Diem H, Rolf B, et al. Kinetics of dendritic cell chimerism and $\mathrm{T}$ cell chimerism in allogeneic hematopoietic stem cell recipients. Bone Marrow Transplant (2006) 37:57-64. doi:10.1038/sj.bmt. 1705217

91. Moratto D, Giliani S, Bonfim C, Mazzolari E, Fischer A, Ochs HD, et al. Longterm outcome and lineage-specific chimerism in 194 patients with WiskottAldrich syndrome treated by hematopoietic cell transplantation in the period 1980-2009: an international collaborative study. Blood (2011) 118:1675-84 doi:10.1182/blood-2010-11-319376

92. Mager K, Wehner R, Bahr F, Oelschlägel U, Platzbecker U, Wermke M, et al. Reconstitution of 6-sulfo LacNAc dendritic cells after allogeneic stem-cell transplantation. Transplantation (2012) 93:1270-5. doi:10.1097/TP. 0b013e31824fd $8 \mathrm{~b} 4$ 
93. Horváth R, Budinský V, Kayserová J, Kalina T, Formánková R, Starý J, et al. Kinetics of dendritic cells reconstitution and costimulatory molecules expression after myeloablative allogeneic haematopoietic stem cell transplantation: implications for the development of acute graft-versus host disease. Clin Immunol (2009) 131:60-9. doi:10.1016/j.clim.2008.10.009

94. Arpinati M, Chirumbolo G, Urbini B, Bonifazi F, Bandini G, Saunthararajah $\mathrm{Y}$, et al. Acute graft-versus-host disease and steroid treatment impair CD11c+ and CD123+ dendritic cell reconstitution after allogeneic peripheral blood stem cell transplantation. Biol Blood Marrow Transplant (2004) 10:106-15. doi:10.1016/j.bbmt.2003.09.005

95. Rajasekar R, Mathews V, Lakshmi KM, Sellathamby S, George B, Viswabandya A, et al. Plasmacytoid dendritic cell count on day 28 in HLA-matched related allogeneic peripheral blood stem cell transplant predicts the incidence of acute and chronic GVHD. Biol Blood Marrow Transplant (2008) 14:344-50. doi:10.1016/j.bbmt.2007.12.494

96. Porta MD, Rigolin GM, Alessandrino EP, Maiocchi M, Malcovati L, Vanelli L, et al. Dendritic cell recovery after allogeneic stem-cell transplantation in acute leukemia: correlations with clinical and transplant characteristics. Eur J Haematol (2004) 72:18-25. doi:10.1046/j.0902-4441. 2004.00172.x

97. Haniffa M, Ginhoux F, Wang XN, Bigley V, Abel M, Dimmick I, et al. Differential rates of replacement of human dermal dendritic cells and macrophages during hematopoietic stem cell transplantation. J Exp Med (2009) 206:371-85. doi:10.1084/jem.20081633

98. Auffermann-Gretzinger S, Eger L, Bornhäuser M, Schäkel K, Oelschlaegel $\mathrm{U}$, Schaich M, et al. Fast appearance of donor dendritic cells in human skin: dynamics of skin and blood dendritic cells after allogeneic hematopoietic cell transplantation. Transplantation (2006) 81:866-73. doi:10.1097/01.tp. 0000203318.16224.57

99. Collin MP, Hart DN, Jackson GH, Cook G, Cavet J, MacKinnon S, et al. The fate of human Langerhans cells in hematopoietic stem cell transplantation. J Exp Med (2006) 203:27-33. doi:10.1084/jem.20051787

100. Schäkel K, Kannagi R, Kniep B, Goto Y, Mitsuoka C, Zwirner J, et al. 6Sulfo LacNAc, a novel carbohydrate modification of PSGL-1, defines an inflammatory type of human dendritic cells. Immunity (2002) 17:289-301. doi:10.1016/S1074-7613(02)00393-X

101. Levenga H, Woestenenk R, Schattenberg AV, Maas F, Jansen JH, Raymakers $\mathrm{R}$, et al. Dynamics in chimerism of $\mathrm{T}$ cells and dendritic cells in relapsed CML patients and the influence on the induction of alloreactivity following donor lymphocyte infusion. Bone Marrow Transplant (2007) 40:585-92. doi:10.1038/sj.bmt.1705777

102. Zhang Y, Louboutin JP, Zhu J, Rivera AJ, Emerson SG. Preterminal host dendritic cells in irradiated mice prime CD8+ T cell-mediated acute graft-versushost disease. J Clin Invest (2002) 109:1335-44. doi:10.1172/JCI200214989

103. Hill GR, Crawford JM, Cooke KR, Brinson YS, Pan L, Ferrara JL. Total body irradiation and acute graft-versus-host disease: the role of gastrointestinal damage and inflammatory cytokines. Blood (1997) 90:3204-13. doi:10.1016/j.bbmt. 2003.09.005

104. Hill GR, Teshima T, Gerbitz A, Pan L, Cooke KR, Brinson YS, et al. Differential roles of IL-1 and TNF-alpha on graft-versus-host disease and graft versus leukemia. J Clin Invest (1999) 104:459-67. doi:10.1172/JCI6896

105. Duffner UA, Maeda Y, Cooke KR, Reddy P, Ordemann R, Liu C, et al. Host dendritic cells alone are sufficient to initiate acute graft-versus-host disease. Immunol (2004) 172:7393-8.

106. Markey KA, Banovic T, Kuns RD, Olver SD, Don AL, Raffelt NC, et al. Conventional dendritic cells are the critical donor APC presenting alloantigen after experimental bone marrow transplantation. Blood (2009) 113:5644-9. doi:10.1182/blood-2008-12-191833

107. Li H, Demetris AJ, McNiff J, Matte-Martone C, Tan HS, Rothstein DM, et al. Profound depletion of host conventional dendritic cells, plasmacytoid dendritic cells, and B cells does not prevent graft-versus-host disease induction. J Immunol (2012) 188:3804-11. doi:10.4049/jimmunol.1102795

108. Wu CJ, Yang XF, McLaughlin S, Neuberg D, Canning C, Stein B, et al. Detection of a potent humoral response associated with immune-induced remission of chronic myelogenous leukemia. J Clin Invest (2000) 106:705-14. doi:10.1172/JCI10196

109. Nishida T, Hudecek M, Kostic A, Bleakley M, Warren EH, Maloney D, et al. Development of tumor-reactive $\mathrm{T}$ cells after nonmyeloablative allogeneic hematopoietic stem cell transplant for chronic lymphocytic leukemia. Clin Cancer Res (2009) 15:4759-68. doi:10.1158/1078-0432.CCR-09-0199

110. Cobbold M, De La Peña H, Norris A, Polefrone JM, Qian J, English AM, et al. MHC class I-associated phosphopeptides are the targets of memory-like immunity in leukemia. Sci Transl Med (2013) 5:203ra125. doi:10.1126/scitranslmed. 3006061

111. Sykes M, Preffer F, McAfee S, Saidman SL, Weymouth D, Andrews DM, et al. Mixed lymphohemopoietic chimerism and graft-versus-lymphoma effects after non-myeloablative therapy and HLA-mismatched bone-marrow transplantation. Lancet (1999) 353:1755-9. doi:10.1016/S0140-6736(98)11135-2

112. Chakraverty R, Eom HS, Sachs J, Buchli J, Cotter P, Hsu R, et al. Host MHC class II+ antigen-presenting cells and CD4 cells are required for CD8-mediated graft-versus-leukemia responses following delayed donor leukocyte infusions. Blood (2006) 108:2106-13. doi:10.1182/blood-2006-03-007427

113. Ghosh A, Koestner W, Hapke M, Schlaphoff V, Länger F, Baumann R, et al. Donor T cells primed on leukemia lysate-pulsed recipient APCs mediate strong graft-versus-leukemia effects across MHC barriers in full chimeras. Blood (2009) 113:4440-8. doi:10.1182/blood-2008-09-181677

114. Xia G, Truitt RL, Johnson BD. Graft-versus-leukemia and graft-versus-host reactions after donor lymphocyte infusion are initiated by host-type antigenpresenting cells and regulated by regulatory $\mathrm{T}$ cells in early and long-term chimeras. Biol Blood Marrow Transplant (2006) 12:397-407. doi:10.1016/j. bbmt.2005.11.519

115. Mapara MY, Kim YM, Wang SP, Bronson R, Sachs DH, Sykes M. Donor lymphocyte infusions mediate superior graft-versus-leukemia effects in mixed compared to fully allogeneic chimeras: a critical role for host antigen-presenting cells. Blood (2002) 100:1903-9. doi:10.1182/blood-2002-01-0023

116. Rocha M, Umansky V, Lee KH, Hacker HJ, Benner A, Schirrmacher V. Differences between graft-versus-leukemia and graft-versus-host reactivity. I. Interaction of donor immune T cells with tumor and/or host cells. Blood (1997) 89:2189-202.

117. Muerkoster S, Laman JD, Rocha M, Umansky V, Schirrmacher V. Functional and in situ evidence for nitric oxide production driven by CD40-CD40L interactions in graft-versus-leukemia reactivity. Clin Cancer Res (2000) 6: 1988-96.

118. Schulz O, Diebold SS, Chen M, Näslund TI, Nolte MA, Alexopoulou L, et al. Toll-like receptor 3 promotes cross-priming to virus-infected cells. Nature (2005) 433:887-92. doi:10.1038/nature03326

119. Fuertes MB, Kacha AK, Kline J, Woo SR, Kranz DM, Murphy KM, et al. Host type I IFN signals are required for antitumor CD8+ T cell responses through CD8\{alpha\}+ dendritic cells. J Exp Med (2011) 208:2005-16. doi:10.1084/jem. 20101159

120. Diamond MS, Kinder M, Matsushita H, Mashayekhi M, Dunn GP, Archambault JM, et al. Type I interferon is selectively required by dendritic cells for immune rejection of tumors. J Exp Med (2011) 208:1989-2003. doi:10.1084/ jem. 20101158

121. Edelson BT, KC W, Juang R, Kohyama M, Benoit LA, Klekotka PA, et al. Peripheral CD103+ dendritic cells form a unified subset developmentally related to CD8alpha+ conventional dendritic cells. J Exp Med (2010) 207:823-36. doi:10.1084/jem.20091627

122. Seillet C, Jackson JT, Markey KA, Brady HJ, Hill GR, Macdonald KP, et al. CD8alpha+ DCs can be induced in the absence of transcription factors Id2, Nfil3, and Batf3. Blood (2013) 121:1574-83. doi:10.1182/blood-2012-07445650

123. Poulin LF, Salio M, Griessinger E, Anjos-Afonso F, Craciun L, Chen JL, et al. Characterization of human DNGR-1+ BDCA3+ leukocytes as putative equivalents of mouse CD8alpha+ dendritic cells. J Exp Med (2010) 207:1261-71. doi:10.1084/jem.20092618

124. Mullighan CG, Su X, Zhang J, Radtke I, Phillips LA, Miller CB, et al. Deletion of IKZF1 and prognosis in acute lymphoblastic leukemia. N Engl J Med (2009) 360:470-80. doi:10.1056/NEJMoa0808253

125. Martinelli G, Iacobucci I, Storlazzi CT, Vignetti M, Paoloni F, Cilloni D, et al. IKZF1 (Ikaros) deletions in BCR-ABL1-positive acute lymphoblastic leukemia are associated with short disease-free survival and high rate of cumulative incidence of relapse: a GIMEMA AL WP report. J Clin Oncol (2009) 27:5202-7. doi:10.1200/JCO.2008.21.6408

126. Li JM, Southerland LT, Lu Y, Darlak KA, Giver CR, McMillin DW, et al. Activation, immune polarization, and graft-versus-leukemia activity of donor T cells 
are regulated by specific subsets of donor bone marrow antigen-presenting cells in allogeneic hemopoietic stem cell transplantation. J Immunol (2009) 183:7799-809. doi:10.4049/jimmunol.0900155

127. Darlak KA, Wang Y, Li JM, Harris WA, Owens LM, Waller EK. Enrichment of IL-12-producing plasmacytoid dendritic cells in donor bone marrow grafts enhances graft-versus-leukemia activity in allogeneic hematopoietic stem cell transplantation. Biol Blood Marrow Transplant (2013) 19:1331-9. doi:10.1016/j.bbmt.2013.06.016

128. Lu Y, Giver CR, Sharma A, Li JM, Darlak KA, Owens LM, et al. IFN-gamma and indoleamine 2,3-dioxygenase signaling between donor dendritic cells and $\mathrm{T}$ cells regulates graft versus host and graft versus leukemia activity. Blood (2012) 119:1075-85. doi:10.1182/blood-2010-12-322891

129. Elmaagacli AH, Steckel NK, Koldehoff M, Hegerfeldt Y, Trenschel R, Ditschkowski M, et al. Early human cytomegalovirus replication after transplantation is associated with a decreased relapse risk: evidence for a putative virus-versus-leukemia effect in acute myeloid leukemia patients. Blood (2011) 118:1402-12. doi:10.1182/blood-2010-08-304121

130. Green ML, Leisenring WM, Xie H, Walter RB, Mielcarek M, Sandmaier $\mathrm{BM}$, et al. CMV reactivation after allogeneic HCT and relapse risk: evidence for early protection in acute myeloid leukemia. Blood (2013) 122:1316-24. doi:10.1182/blood-2013-02-487074

131. Manjappa S, Bhamidipati PK, Stokerl-Goldstein KE, Dipersio JF, Uy GL, Westervelt $\mathrm{P}$, et al. Protective effect of cytomegalovirus reactivation on relapse after allogeneic hematopoietic cell transplantation in acute myeloid leukemia patients is influenced by conditioning regimen. Biol Blood Marrow Transplant (2013) 20(1):46-52. doi:10.1016/j.bbmt.2013.10.003

132. Foley B, Cooley S, Verneris MR, Pitt M, Curtsinger J, Luo X, et al. Cytomegalovirus reactivation after allogeneic transplantation promotes a lasting increase in educated NKG2C+ natural killer cells with potent function. Blood (2012) 119:2665-74. doi:10.1182/blood-2011-10-386995

133. Andoniou CE, van Dommelen SL, Voigt V, Andrews DM, Brizard G, AsselinPaturel C, et al. Interaction between conventional dendritic cells and natural killer cells is integral to the activation of effective antiviral immunity. Nat Immunol (2005) 6:1011-9. doi:10.1038/ni1244

134. Ebihara T, Azuma M, Oshiumi H, Kasamatsu J, Iwabuchi K, Matsumoto K, et al. Identification of a polyI:C-inducible membrane protein that participates in dendritic cell-mediated natural killer cell activation. J Exp Med (2010) 207:2675-87. doi:10.1084/jem.20091573

135. Joffre OP, Segura E, Savina A, Amigorena S. Cross-presentation by dendritic cells. Nat Rev Immunol (2012) 12:557-69. doi:10.1038/nri3254

136. Savina A, Peres A, Cebrian I, Carmo N, Moita C, Hacohen N, et al. The small GTPase Rac2 controls phagosomal alkalinization and antigen crosspresentation selectively in CD8(+) dendritic cells. Immunity (2009) 30:544-55. doi:10.1016/j.immuni.2009.01.013

137. Cebrian I, Visentin G, Blanchard N, Jouve M, Bobard A, Moita C, et al. Sec22b regulates phagosomal maturation and antigen crosspresentation by dendritic cells. Cell (2011) 147:1355-68. doi:10.1016/j.cell.2011.11.021

138. Imai T, Kato Y, Kajiwara C, Mizukami S, Ishige I, Ichiyanagi T, et al. Heat shock protein 90 (HSP90) contributes to cytosolic translocation of extracellular antigen for cross-presentation by dendritic cells. Proc Natl Acad Sci U S A (2011) 108:16363-8. doi:10.1073/pnas.1108372108

139. Ackerman AL, Kyritsis C, Tampe R, Cresswell P. Access of soluble antigens to the endoplasmic reticulum can explain cross-presentation by dendritic cells. Nat Immunol (2005) 6:107-13. doi:10.1038/ni1147

140. Shen L, Sigal LJ, Boes M, Rock KL. Important role of cathepsin S in generating peptides for TAP-independent MHC class I crosspresentation in vivo. Immunity (2004) 21:155-65. doi:10.1016/j.immuni.2004.07.004

141. Di Pucchio T, Chatterjee B, Smed-Sörensen A, Clayton S, Palazzo A, Montes $\mathrm{M}$, et al. Direct proteasome-independent cross-presentation of viral antigen by plasmacytoid dendritic cells on major histocompatibility complex class I. Nat Immunol (2008) 9:551-7. doi:10.1038/ni.1602

142. Mashayekhi M, Sandau MM, Dunay IR, Frickel EM, Khan A, Goldszmid RS, et al. CD8alpha(+) dendritic cells are the critical source of interleukin-12 that controls acute infection by Toxoplasma gondii tachyzoites. Immunity (2011) 35:249-59. doi:10.1016/j.immuni.2011.08.008

143. Edelson BT, Bradstreet TR, Hildner K, Carrero JA, Frederick KE, KC W, et al. CD8alpha(+) dendritic cells are an obligate cellular entry point for productive infection by Listeria monocytogenes. Immunity (2011) 35:236-48. doi:10.1016/j.immuni.2011.06.012
144. del Rio ML, Rodriguez-Barbosa JI, Kremmer E, Forster R. CD103- and CD103+ bronchial lymph node dendritic cells are specialized in presenting and cross-presenting innocuous antigen to CD4+ and CD8+ T cells. J Immunol (2007) 178:6861-6.

145. Bedoui S, Whitney PG, Waithman J, Eidsmo L, Wakim L, Caminschi I, et al. Cross-presentation of viral and self antigens by skin-derived CD103+ dendritic cells. Nat Immunol (2009) 10:488-95. doi:10.1038/ni.1724

146. Henri S, Poulin LF, Tamoutounour S, Ardouin L, Guilliams M, de Bovis B, et al. CD207+ CD103+ dermal dendritic cells cross-present keratinocyte-derived antigens irrespective of the presence of Langerhans cells. J Exp Med (2010) 207:189-206. doi:10.1084/jem.20091964

147. Helft J, Manicassamy B, Guermonprez P, Hashimoto D, Silvin A, Agudo J, et al. Cross-presenting CD103+ dendritic cells are protected from influenza virus infection. J Clin Invest (2012) 122:4037-47. doi:10.1172/JCI60659

148. Schreibelt G, Klinkenberg LJ, Cruz LJ, Tacken PJ, Tel J, Kreutz M, et al. The Ctype lectin receptor CLEC9A mediates antigen uptake and (cross-)presentation by human blood BDCA3+ myeloid dendritic cells. Blood (2012) 119:2284-92. doi:10.1182/blood-2011-08-373944

149. Cohn L, Chatterjee B, Esselborn F, Smed-Sörensen A, Nakamura N, Chalouni $\mathrm{C}$, et al. Antigen delivery to early endosomes eliminates the superiority of human blood BDCA3+ dendritic cells at cross presentation. J Exp Med (2013) 210:1049-63. doi:10.1084/jem.20121251

150. Haniffa M, Shin A, Bigley V, McGovern N, Teo P, See P, et al. Human tissues contain CD141hi cross-presenting dendritic cells with functional homology to mouse CD103+ nonlymphoid dendritic cells. Immunity (2012) 37:60-73. doi:10.1016/j.immuni.2012.04.012

151. Segura E, Durand M, Amigorena S. Similar antigen cross-presentation capacity and phagocytic functions in all freshly isolated human lymphoid organresident dendritic cells. J Exp Med (2013) 210:1035-47. doi:10.1084/jem. 20121103

152. Dolan BP, Gibbs KD Jr, Ostrand-Rosenberg S. Dendritic cells cross-dressed with peptide MHC class I complexes prime CD8+ T cells. J Immunol (2006) 177:6018-24.

153. Dolan BP, Gibbs KD Jr, Ostrand-Rosenberg S. Tumor-specific CD4+ T cells are activated by "cross-dressed" dendritic cells presenting peptide-MHC class II complexes acquired from cell-based cancer vaccines. J Immunol (2006) 176:1447-55

154. Wakim LM, Bevan MJ. Cross-dressed dendritic cells drive memory CD8+ Tcell activation after viral infection. Nature (2011) 471:629-32. doi:10.1038/ nature 09863

155. Li L, Kim S, Herndon JM, Goedegebuure P, Belt BA, Satpathy AT, et al. Crossdressed CD8alpha+/CD103+ dendritic cells prime CD8+ T cells following vaccination. Proc Natl Acad Sci U S A (2012) 109:12716-21. doi:10.1073/pnas. 1203468109

156. Miyake T, Kumagai Y, Kato H, Guo Z, Matsushita K, Satoh T, et al. Poly I:Cinduced activation of NK cells by CD8 alpha+ dendritic cells via the IPS-1 and TRIF-dependent pathways. J Immunol (2009) 183:2522-8. doi:10.4049/ jimmunol.0901500

157. Longhi MP, Trumpfheller C, Idoyaga J, Caskey M, Matos I, Kluger C, et al. Dendritic cells require a systemic type I interferon response to mature and induce CD4+ Th1 immunity with poly IC as adjuvant. J Exp Med (2009) 206:1589-602. doi:10.1084/jem.20090247

158. Robb RJ, Kreijveld E, Kuns RD, Wilson YA, Olver SD, Don AL, et al. Type IIFNs control GVHD and GVL responses after transplantation. Blood (2011) 118:3399-409. doi:10.1182/blood-2010-12-325746

159. Li H, Li Y, Jiao J, Hu HM. Alpha-alumina nanoparticles induce efficient autophagy-dependent cross-presentation and potent antitumour response. Nat Nanotechnol (2011) 6:645-50. doi:10.1038/nnano.2011.153

160. Mukai Y, Yoshinaga T, Yoshikawa M, Matsuo K, Yoshikawa T, Matsuo K, et al. Induction of endoplasmic reticulum-endosome fusion for antigen crosspresentation induced by poly (gamma-glutamic acid) nanoparticles. J Immunol (2011) 187:6249-55. doi:10.4049/jimmunol.1001093

161. Flinsenberg TW, Compeer EB, Koning D, Klein M, Amelung FJ, van Baarle $\mathrm{D}$, et al. Fcgamma receptor antigen targeting potentiates cross-presentation by human blood and lymphoid tissue BDCA-3+ dendritic cells. Blood (2012) 120:5163-72. doi:10.1182/blood-2012-06-434498

162. Crespo MI, Zacca ER, Núñez NG, Ranocchia RP, Maccioni M, Maletto BA, et al. TLR7 triggering with polyuridylic acid promotes cross-presentation in CD8alpha+ conventional dendritic cells by enhancing antigen preservation 
and MHC class I antigen permanence on the dendritic cell surface. J Immunol (2013) 190:948-60. doi:10.4049/jimmunol.1102725

163. Li Y, Hahn T, Garrison K, Cui ZH, Thorburn A, Thorburn J, et al. The vitamin E analogue alpha-TEA stimulates tumor autophagy and enhances antigen crosspresentation. Cancer Res (2012) 72:3535-45. doi:10.1158/0008-5472.CAN-113103

164. Li N, Chen Y, He W, Yi T, Zhao D, Zhang C, et al. Anti-CD3 preconditioning separates GVL from GVHD via modulating host dendritic cell and donor Tcell migration in recipients conditioned with TBI. Blood (2009) 113:953-62. doi:10.1182/blood-2008-06-165522

165. Asakura S, Hashimoto D, Takashima S, Sugiyama H, Maeda Y, Akashi $\mathrm{K}$, et al. Alloantigen expression on non-hematopoietic cells reduces graft-versus-leukemia effects in mice. J Clin Invest (2010) 120:2370-8. doi: 10.1172/JCI39165

166. Reddy P, Sun Y, Toubai T, Duran-Struuck R, Clouthier SG, Weisiger E et al. Histone deacetylase inhibition modulates indoleamine 2,3-dioxygenasedependent DC functions and regulates experimental graft-versus-host disease in mice. J Clin Invest (2008) 118:2562-73. doi:10.1172/JCI34712

167. Zhou Q, Munger ME, Highfill SL, Tolar J, Weigel BJ, Riddle M, et al. Program death-1 signaling and regulatory $\mathrm{T}$ cells collaborate to resist the function of adoptively transferred cytotoxic $\mathrm{T}$ lymphocytes in advanced acute myeloid leukemia. Blood (2010) 116:2484-93. doi:10.1182/blood-2010-03275446

168. Hobo W, Maas F, Adisty N, de Witte T, Schaap N, van der Voort R, et al. siRNA silencing of PD-L1 and PD-L2 on dendritic cells augments expansion and function of minor histocompatibility antigen-specific CD8+ T cells. Blood (2010) 116:4501-11. doi:10.1182/blood-2010-04-278739

169. Willingham SB, Volkmer JP, Gentles AJ, Sahoo D, Dalerba P, Mitra SS, et al. The CD47-signal regulatory protein alpha (SIRPa) interaction is a therapeutic target for human solid tumors. Proc Natl Acad Sci U S A (2012) 109:6662-7. doi:10.1073/pnas.1121623109

170. Weiskopf K, Ring AM, Ho CC, Volkmer JP, Levin AM, Volkmer AK, et al. Engineered SIRPalpha variants as immunotherapeutic adjuvants to anticancer antibodies. Science (2013) 341:88-91. doi:10.1126/science. 1238856

171. McKenna HJ, Stocking KL, Miller RE, Brasel K, De Smedt T, Maraskovsky E, et al. Mice lacking flt3 ligand have deficient hematopoiesis affecting hematopoietic progenitor cells, dendritic cells, and natural killer cells. Blood (2000) 95:3489-97.

172. Waskow C, Liu K, Darrasse-Jèze G, Guermonprez P, Ginhoux F, Merad $\mathrm{M}$, et al. The receptor tyrosine kinase Flt3 is required for dendritic cell development in peripheral lymphoid tissues. Nat Immunol (2008) 9:676-83. doi:10.1038/ni.1615

173. Hochrein H, Shortman K, Vremec D, Scott B, Hertzog P, O'Keeffe M. Differential production of IL-12, IFN-alpha, and IFN-gamma by mouse dendritic cell subsets. J Immunol (2001) 166:5448-55.

174. Guermonprez P, Helft J, Claser C, Deroubaix S, Karanje H, Gazumyan A, et al. Inflammatory Flt3L is essential to mobilize dendritic cells and for $\mathrm{T}$ cell responses during Plasmodium infection. Nat Med (2013) 19:730-8. doi:10.1038/nm.3197

175. Suss G, Shortman K. A subclass of dendritic cells kills CD4 T cells via Fas/Fasligand-induced apoptosis. J Exp Med (1996) 183:1789-96. doi:10.1084/jem. 183.4.1789

176. Chu CC, Ali N, Karagiannis P, Di Meglio P, Skowera A, Napolitano L, et al. Resident CD141 (BDCA3)+ dendritic cells in human skin produce IL-10 and induce regulatory $\mathrm{T}$ cells that suppress skin inflammation. J Exp Med (2012) 209:935-45. doi:10.1084/jem.20112583

177. Wu L, D’Amico A, Winkel KD, Suter M, Lo D, Shortman K. RelB is essential for the development of myeloid-related CD8alpha- dendritic cells but not of lymphoid-related CD8alpha+ dendritic cells. Immunity (1998) 9:839-47. doi:10.1016/S1074-7613(00)80649-4

178. Kobayashi T, Walsh PT, Walsh MC, Speirs KM, Chiffoleau E, King CG, et al. TRAF6 is a critical factor for dendritic cell maturation and development. Immunity (2003) 19:353-63. doi:10.1016/S1074-7613(03)00230-9

179. Yrlid U, Wick MJ. Antigen presentation capacity and cytokine production by murine splenic dendritic cell subsets upon Salmonella encounter. J Immunol (2002) 169:108-16.

180. McDonnell AM, Prosser AC, van Bruggen I, Robinson BW, Currie AJ. CD8alpha+ DC are not the sole subset cross-presenting cell-associated tumor antigens from a solid tumor. Eur J Immunol (2010) 40:1617-27. doi:10.1002/ eji.200940153

181. Li HS, Yang CY, Nallaparaju KC, Zhang H, Liu YJ, Goldrath AW, et al. The signal transducers STAT5 and STAT3 control expression of Id2 and E2-2 during dendritic cell development. Blood (2012) 120:4363-73. doi:10.1182/blood-2012 07-441311

182. Esashi E, Wang YH, Perng O, Qin XF, Liu YJ, Watowich SS. The signal transducer STAT5 inhibits plasmacytoid dendritic cell development by suppressing transcription factor IRF8. Immunity (2008) 28:509-20. doi:10.1016/j.immuni. 2008.02.013

183. Mouriès J, Moron G, Schlecht G, Escriou N, Dadaglio G, Leclerc C. Plasmacytoid dendritic cells efficiently cross-prime naive $\mathrm{T}$ cells in vivo after TLR activation. Blood (2008) 112:3713-22. doi:10.1182/blood-2008-03-146290

184. Segura E, Touzot M, Bohineust A, Cappuccio A, Chiocchia G, Hosmalin A, et al. Human inflammatory dendritic cells induce Th17 cell differentiation. Immunity (2013) 38:336-48. doi:10.1016/j.immuni.2012.10.018

185. Plantinga M, Guilliams M, Vanheerswynghels M, Deswarte K, Branco-Madeira F, Toussaint W, et al. Conventional and monocyte-derived CD11b(+) dendritic cells initiate and maintain T helper 2 cell-mediated immunity to house dust mite allergen. Immunity (2013) 38:322-35. doi:10.1016/j.immuni.2012.10.016

186. Leon B, Lopez-Bravo M, Ardavin C. Monocyte-derived dendritic cells formed at the infection site control the induction of protective $\mathrm{T}$ helper 1 responses against Leishmania. Immunity (2007) 26:519-31. doi:10.1016/j.immuni.2007. 01.017

187. Hohl TM, Rivera A, Lipuma L, Gallegos A, Shi C, Mack M, et al. Inflammatory monocytes facilitate adaptive CD4 T cell responses during respiratory fungal infection. Cell Host Microbe (2009) 6:470-81. doi:10.1016/j.chom.2009.10.007

188. Nakano H, Lin KL, Yanagita M, Charbonneau C, Cook DN, Kakiuchi T, et al. Blood-derived inflammatory dendritic cells in lymph nodes stimulate acute T helper type 1 immune responses. Nat Immunol (2009) 10:394-402. doi:10.1038/ni.1707

Conflict of Interest Statement: The authors declare that the research was conducted in the absence of any commercial or financial relationships that could be construed as a potential conflict of interest.

Received: 05 November 2013; accepted: 05 February 2014; published online: 21 February 2014.

Citation: Toubai T, Mathewson N and Reddy P (2014) The role of dendritic cells in graft-versus-tumor effect. Front. Immunol. 5:66. doi: 10.3389/fimmu.2014.00066

This article was submitted to Tumor Immunity, a section of the journal Frontiers in Immunology.

Copyright (C) 2014 Toubai, Mathewson and Reddy. This is an open-access article distributed under the terms of the Creative Commons Attribution License (CC BY). The use, distribution or reproduction in other forums is permitted, provided the original author(s) orlicensor are credited and that the original publication in this journal is cited, in accordance with accepted academic practice. No use, distribution or reproduction is permitted which does not comply with these terms. 